\title{
The servicescape as an antecedent to service quality and behavioral intentions
}

\author{
Daire Hooper and foseph Coughlan \\ College of Business, Dublin Institute of Technology, Dublin, Ireland \\ Michael R. Mullen \\ Department of Marketing, Barry Kaye College of Business, Florida Atlantic University, Fort Lauderdale, Florida, USA
}

\begin{abstract}
Purpose - The purpose of this paper is to examine whether the servicescape should be subsumed as a dimension within service quality conceptualizations or whether it is a unique construct in itself which precedes service quality evaluations and behavioral intentions. The authors both propose and operationalize this model and in doing so make a theoretical contribution by demonstrating how a delineation between these two constructs is necessary in order for theory to progress in this area.

Design/methodology/approach - A total of 355 customers were intercepted as they exited a retail store and surveyed using a structured questionnaire. The data were then analyzed using structural equation modeling to test the research hypotheses.

Findings - This paper finds that it is more appropriate to model the servicescape as a separate construct which precedes service quality thus highlighting a need for a demarcation to be made between these important constructs. In addition, the authors find that design is a significant contributor to behavioral intentions further confirming the necessity to manage service environments in order to generate repatronage behaviors. Practical implications - Service providers should consider the influence of store environments in shaping service quality perceptions and their subsequent impact on behavioral intentions.

Originality/value - The paper adds to the existing literature by disentangling the complicated relationships between service environments, service quality and behavioral intentions. Furthermore, the findings indicate to practitioners which aspects of the servicescape require attention so as to maximize repatronage intentions.
\end{abstract}

Keywords Store environments, Servicescapes, Behavioural intentions, Service quality, Shops, Customer services quality

Paper type Research paper

An executive summary for managers and executive readers can be found at the end of this article.

\section{Introduction}

For consumers visiting a service or retail store, the service environment is the first aspect of the service that is perceived by the customer and it is at this stage that consumers are likely to form impressions of the level of service they will receive. Indeed, it is an old cliché that you never get a second chance to make a first impression and for this reason, it is argued herein, that the service environment should be viewed as an antecedent to service quality perceptions. This perspective conflicts with much of the service quality literature which includes tangible cues as a core dimension alongside a range of other service quality indicators. This article demonstrates how it is theoretically more prudent to model the servicescape as a predecessor to service quality evaluations. To do so, the article begins by providing an overview of the servicescapes literature, paying particular attention to the various dimensions proffered in the literature. Following on from

The current issue and full text archive of this journal is available at www.emeraldinsight.com/0887-6045.htm

Journal of Services Marketing

27/4 (2013) 271-280

(C) Emerald Group Publishing Limited [ISSN 0887-6045]

[DOI 10.1108/08876041311330753] this, we examine the service quality literature and from this it becomes evident of the overlap between the two constructs.

Since the term the "servicescape" was first coined by Bitner (1992), a steady stream of research has sought to demonstrate the impact of servicescapes on various post-consumption constructs such as emotion, customer satisfaction (Johnson et al., 2004), store image (Baker et al., 1994), service quality (Hightower et al., 2002; Reimer and Kuehn, 2005), value for money (O'Cass and Grace, 2008), behavioral intentions (Harris and Ezeh, 2008) and financial performance (Brüggen et al., 2009). On the whole, the positive effects of the servicescape on these constructs has been demonstrated and the general consensus supports the important role servicescapes play. In more recent years, research has extended much of this theory to virtual servicescapes with numerous papers demonstrating their effects on consumer behaviors (Vilnai-Yavetz and Rafaeli, 2007; Harris and Goode, 2010). There have also been a number of qualitative papers published in this area and these have again shown the importance of service environments on maintaining customer relationships over time (Menzel-Baker et al., 2007; Grayson and McNeill, 2009; Tuzovic, 2009) However, on a conceptual level certain ambiguities remain. For instance, there is little agreement between authors as to what constitutes the servicescape and it is unclear what should

Received 17 June 2011

Revised 4 January 2012

Accepted 8 March 2012 
be regarded as a servicescape dimension and what the content of these dimensions should be. Furthermore, it is unclear whether the servicescape should be regarded as an additional service quality element, or whether it should be viewed as a separate construct in itself. While different approaches to describing service quality have been proffered in the literature, the most frequently cited and influential is Parasuraman et al.'s (1985, 1988, 1994) SERVQUAL conceptualization. Although this model is not without its detractors, it has withstood many of the criticisms leveled at it and is now a stalwart of services marketing management theory.

The purpose of this study is to develop a theoretical model of servicescapes and to demonstrate how store environment perceptions precede a two dimensional view of service quality which are then modeled together as antecedents of behavioral outcomes. Firstly, we consider the servicescapes literature, which thus forms the basis of our model. Next the service quality literature is considered and a theoretical justification for modeling the servicescape as a precursor to service quality perceptions is provided leading to the hypothesized model. Following development of the theoretical model, we present research methods, results, a discussion of the theoretical, managerial implications and a conclusion.

\section{Literature review}

\subsection{Servicescpes}

Although "the servicescape" is probably the most widely used term to refer to the influence of tangible and intangible cues on consumers, there are three other appellations that are commonly used to describe the same concept, these being; atmospherics, environmental psychology and store environments. The literature surrounding each of these is derived from Mehrabian and Russell's (1974) work on environmental psychology however, certain discrepancies exist which can most likely be attributed to the corpus of literature from which they are derived.

The first term popularly used is "environmental psychology", and those that coined this expression are not surprisingly, from a psychology background (Mehrabian and Russell, 1974). Mehrabian and Russell's (1974) theory lies at the core of this work with researchers directly applying their theory albeit in a consumer context (Donovan and Rossiter, 1982). The second term used in the literature, "atmospherics", can be traced back to Kotler's (1974, p. 50) seminal article in which he argued that atmospherics is "the conscious designing of space to create certain effects in buyers". He contended that environmental elements within the service environment such as noises, shapes, scents, music and color can be modified so that particular emotional effects will be elicited which in turn enhance purchase probability. This conceptualization is similar to Mehrabian and Russell's (1974) in that they both infer that environmental stimuli can be manipulated so that certain behaviors manifest. Although some see Kotler (1974) as the first to advocate the manipulation of environmental cues in order to affect consumer behavior, a number of studies previous to this had manipulated environmental elements (Smith and Curnow, 1966; Kotzan and Evanson, 1969). In general, researchers who use the term atmospherics tend to focus on one or two environmental stimuli and measure how they impact upon internal responses (such as emotions) and behavioral responses (such as spending more time in-store) with a wealth of studies within this area demonstrating these causal linkages (Turley and Milliman, 2000; Summers and Herbert, 2001; Michon et al., 2005; Lin, 2010). The third stream of study has emerged from the retail literature and aptly refers to this area of research as the "store environments" (Baker, 1987; Baker et al., 1994, 2002). Unlike the work of atmospherics authors, those who have taken this view have attempted to take an all-inclusive approach to the measurement of the environment by including multiple environmental stimuli (Baker et al., 1994, 2002). Much of the recent empirical research on servicescapes has taken this multi-dimensional perspective (Sherman et al., 1997; Wakefield and Blodgett, 1996; Wakefield and Blodgett, 1999) although there seems to be some discrepancies with regards to their servicescapes measures. However, close examination of the literature finds that a number of common themes emerge that are relatively generic and could be applied to a variety of service industries.

The first of these is ambient conditions and it is this aspect of the service that is most likely to affect one of the five senses (Bitner, 1992). It is thought that when ambient factors are maintained at a satisfactory level they do not directly motivate consumer purchases, however if any of these ambient cues fall outside their acceptable limits, or are absent from the environment, they have negative effects on consumer behavior (Baker, 1987; Hightower et al., 2002). It can be seen from the atmospherics literature that ambient cues are one of the most widely studied aspects of the servicescape (Turley and Milliman, 2000) with an extensive range of ambience factors studied including music (Milliman, 1986; Yalch and Spangenberg, 1990; Areni and Kim, 1993; Herrington and Capella, 1994; Dubé et al., 1995; Herrington and Capella, 1996; Yalch and Spangenberg, 2000; Chebat et al., 2001; Jacob, 2006), lighting (Areni and Kim, 1994; Summers and Herbert, 2001) and olfactory cues (Bone and Ellen, 1999; Davies et al., 2003; Ward et al., 2003).

The second commonly found dimension relates to design cues which unlike ambient cues are more visual in nature. The design aspect of the servicescape is possibly one of the most important as it facilitates the communication of a multitude of messages to the consumer from how to behave, to the service levels they should expect to receive (Bitner, 1992). Scholars generally categorize design elements as being either functional or aesthetic with issues ranging from architectural design, to the materials and the colors used in the decor (Baker, 1987). Space and layout also occur frequently in the literature and generally relate to the way furnishings and equipment are arranged and the spatial relationships among these objects (Bitner, 1992; Wakefield and Blodgett, 1996; Ryu and Jang, 2007). Ideally, the positioning of objects and furnishings within the environment should facilitate the free flow of movement throughout the service facility and ought to allow customers to accomplish their tasks during the service encounter (Grayson and McNeill, 2009). For example, aisle space must be sufficiently large so as to permit shoppers to browse comfortably without feeling crowded or cramped (Harrell et al., 1980; Eroglu and Harrell, 1986; Hui and Bateson, 1991). For self-service store environments, the issue of space is likely to be more pertinent as customers must navigate through the structure of the facility to serve themselves. Furthermore, employing "user-friendly" layout designs should improve customer search time and service reliability 
thus facilitating service delivery (Sulek and Lind, 1995). On the other hand, if the layout is such that it inhibits movement throughout the environment it may lead to frustration which leads to a more dissatisfying experience for the customer (Bitner, 1992).

The role of equipment has also repeatedly appeared in the literature. While some services may be more equipmentdependent, in practically all services there is likely to be some element of contact with equipment by the customer. For selfservice situations this aspect of the service environment is likely to have a significant impact upon consumer evaluations of the service as it determines how well the consumer can perform various tasks. This dimension is also critical in communicating the image of the store to customers with outdated tills and technology implying that the quality of service that the customer should expect is below average. A critical incident study by Hoffman et al. (2003) supported this notion as it was found that a significant proportion of servicescape failures were attributed to mechanical problems such as inoperative computers and other equipment which subsequently inconvenienced the customer. From this, and other studies which have analyzed the role of equipment in the service encounter we believe this is an important aspect to servicescape design in the twenty-first century.

A final dimension which is frequently cited in the literature is the role of hygiene and cleanliness. This servicescape dimension seems the most intuitive and possibly easiest to maintain but requires constant attention from the service provider. Despite the relative ease at which this dimension can be controlled, Hoffman et al. (2003) report that cleanliness issues are the most frequently cited servicescape failures by consumers. In fact, cleanliness issues are regarded by respondents as being the most serious service failures experienced. It is likely that this is due to the fact that maintaining a clean and hygienic environment should be one of the cheapest and easiest of the servicescape dimensions to control.

\subsection{Two dimensions of service quality}

Examination of the service quality literature generally finds that most authors define service quality as an overall appraisal of a product or service that is dependent on consumers' prior expectations (Grönroos, 1984; Bitner and Hubbert, 1994) and it is this consumer-centric definition that prevails most commonly in the literature. Many service quality theories describe service quality as a multi-dimensional construct, but although authors do not necessarily agree with the content or number of the dimensions, one sub-construct which is continually classified as a service quality element in some way or another are tangible cues. Parasuraman et al. (1985, 1988, 1991, 1994) include a tangibles dimension within their SERVQUAL framework which incorporates the appearance and design of the physical facilities, the appropriateness of the equipment used and also how the employees are presented. Similarly, Brady and Cronin (2001), Rust and Oliver (1994) and more recently Wall and Berry (2007) and Pollack (2009) all describe how service quality can be inferred from the quality of the service environment. Bitner's (1992, p. 63) seminal piece on servicescapes makes no explicit references to any service quality model per se, instead she notes that "customers [...] tend to use extrinsic cues (such as the physical surroundings) to infer quality". From this it can be seen that Bitner (1992) believes that the servicescape contributes to consumers' perceptions of service quality but how this should be modeled is unclear. As part of a larger model, Hightower et al. (2002) found that the servicescape is a predictor of perceived service quality, however, the theoretical implications of this were not discussed. We argue that there needs to be a demarcation made between these two constructs and that servicescape evaluations should precede service quality perceptions as this element of the service is immediately evident to a customer. Moreover, a customer may actually use the servicescape to mold their perceptions of the personal service they are about to receive in which case the servicescape acts as an expectations primer. For these reasons we propose that the servicescape should be modeled as an antecedent to service quality. Further to this, we propose that service quality should be regarded as a two dimensional structure. This is in line with a number of authors" work in this area (Brady and Cronin, 2001; Wall and Berry, 2007) but primarily stems from Grönroos's (1984) original model. Grönroos (1984) describes service quality consisting of a technical and a functional service quality dimension. The functional dimension relates to how the service is delivered whereas the technical aspect refers to what the customer actually receives. From this we can see that the "how" aspect of this model relates primarily to the role employees play in the service delivery whereas the "what" is more akin to a general or overall service evaluation. Using this as a basis, we propose that consumers' perceptions of employee service quality has a direct impact on overall service evaluations, thus in a sense moving away from Grönroos's (1984) original framework as we believe a four-step relationship where servicescape evaluations precede employee service quality which in turn has a direct effect on outcome, or overall service quality is more appropriate. The following hypotheses reflect this supposition:

H1. Servicescape perceptions will have a direct and positive effect on employee service quality.

H2. Servicescape perceptions will have a direct and positive effect on overall service quality.

H3. Employee service quality will have a direct and positive effect on overall service quality.

On the whole the literature has pointed to the fact that a favorable service experience will result in positive behavioral responses (Zeithaml et al., 1996) with high levels of service quality thought to be an essential ingredient of a business's survival. Indeed the quality of the service received will ultimately determine whether an individual engages in both positive word-of-mouth communications and repatronage behaviors. Numerous studies over the years have demonstrated the positive relationship between service quality and repatronage intentions. Keaveney's (1995) seminal paper on the causes of customer switching behavior found that consumers switch for a variety of reasons, however most of these reasons were related to service quality failures. In line with this research we propose the following hypothesis:

H4. Servicescape perceptions will have a direct and positive effect on behavioral intentions.

H5. Overall service quality will have a direct and positive impact on behavioral intentions.

Figure 1 reflects each of these hypotheses which describes the servicescape as a direct antecedent to employee service quality and having a indirect impact on overall service quality 
Figure 1 Theoretical model of the servicescape, service quality and behavioral intentions

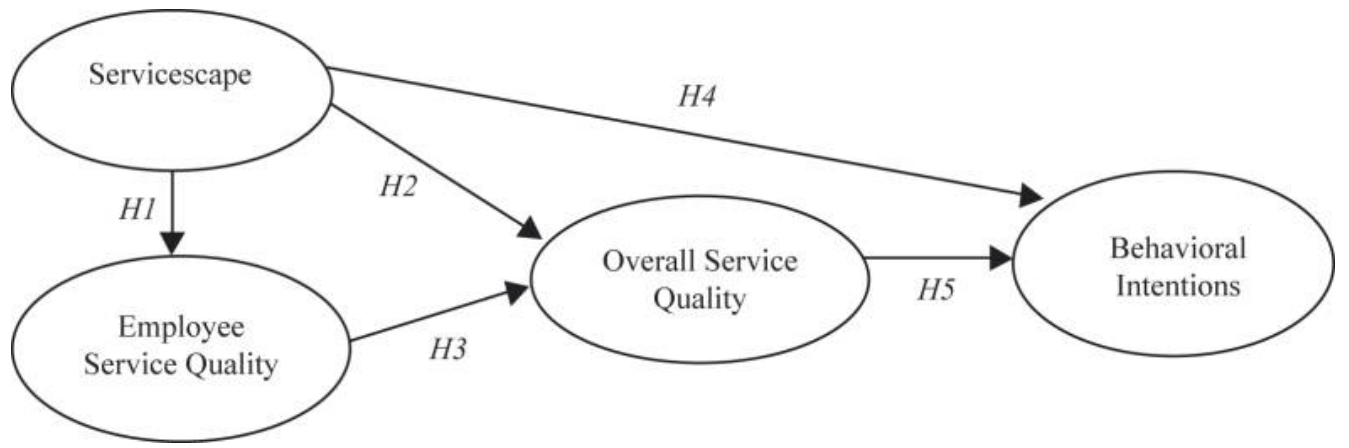

evaluations. Servicesapes and overall service quality subsequently have a direct impact on behavioral intentions.

\section{Method}

\subsection{Study context}

Data for this study was collected in service stations in Dublin, Ireland. As well as selling petrol and petrol-related products, the service stations also include a convenience store which sell a variety of hot and cold food in addition to a selection of grocery items. Given that the chosen service was retailing, it was decided that a survey intercept technique would be most appropriate. This was a logical approach as it allowed us to sample individuals who had used the service in the time immediately before completing the survey. Interviewers were graduate students who were trained and observed. They were instructed to interview customers exiting the store only. Data collection took place over two weeks and yielded a sample size of 355 of which 34 percent were female and 66 percent were male.

\subsection{Measures}

All respondents provided the information on a structured questionnaire which addressed the pertinent research questions. We view the servicescape as a multi-dimensional construct with multiple items for each servicescape dimension. These items were taken from a variety of sources, however as there were no items to reflect certain aspects of the service environment, these were created by the authors. A pilot test was run which validated these items. A full list of items and sources can be found in Table I. All items were in statement form and were rated by respondents on seven-point Likert scales from Strongly Disagree to Strongly Agree.

\subsection{Data analyses and results}

Data collected from respondents was analyzed with confirmatory factor analysis (CFA) and structural equation modeling. Firstly the data was examined for normality and outliers (Mullen et al., 1995) and as no problems were noted here we proceeded to follow Anderson and Gerbing's (1988) recommended two-step approach to assess the measurement model. This allowed for individual items to be assessed for composite reliability, convergent reliability and discriminant validity. Harman's one-factor method was also used to test for common methods bias (Podsakoff et al., 2003). The analysis looked at the factor loadings, the internal consistency of items, discriminant validity and convergent validity resulting in the deletion of a number of service quality items.

Reliabilities and confirmatory factor properties for the full model are shown in Table II. Discriminant validity was tested using Bagozzi et al.'s (1991) recommendations and it was found that the phi coefficients between all constructs were significantly less than 1.0. Although the model yielded a significant chi-square, this is not surprising as when larger samples are used this statistic reaches significance very easily. The remaining fit indices indicated an excellent fit $\left(\chi^{2}=209.21, \quad \mathrm{df}=83, \quad p=0.000, \quad \mathrm{RMSEA}=0.067\right.$, $\mathrm{CFI}=0.95, \quad \mathrm{SRMR}=0.058)$ and were well within recommended threshold levels (Hooper et al. 2008). Composite reliabilities were also above Bagozzi and Yi's (1991) 0.60 threshold and these are also displayed in Table II which allows us to discuss each of the hypotheses separately. Table III shows all standardized structural parameter estimates and the results of the hypotheses tests for the model.

As expected, $H 1$ which links servicescape perceptions with employee service quality is found to be significant and positive $\left(\gamma_{11}=0.66, t=8.83, p=0.04\right)$. Thus, positive servicescape evaluations are likely to lead to more positive perceptions of employee service quality. The direct effect of servicescapes on overall service quality (H2) was found to be both positive and significant $\left(\gamma_{21}=0.27, t=3.14, p=0.07\right)$. H3, which predicted a positive relationship between employee service quality and overall service quality was also supported $\left(\beta_{12}=0.45, t=5.02, p=0.14\right)$. As expected, the direct effect of servicescapes on behavioral intentions $(H 4)$ was both significant and positive $\left(\gamma_{11}=0.44, t=3.39, p=0.09\right)$. H5, predicting a positive relationship between overall service quality and behavioral intentions was also supported $\left(\beta_{13}=0.25, t=3.39, p=0.09\right)$. From this we can see that the results support all our hypothesis in that the paths are all significant and in the expected direction. Overall, these results support our theoretical model and provide evidence for the servicescape as a predictor of service quality rather than an additional dimension to be subsumed within the construct. Furthermore, our results also indicate that the servicescape is a powerful determinant of overall service quality perceptions as well as repatronage and word-of-mouth behaviors.

\section{Discussion}

The aim of this paper was to test the effects of the servicescape and two dimensions of service quality on behavioral intentions. A structural model investigated whether the servicescape is an antecedent to the two 
Table I Constructs with measures and sources

\begin{tabular}{|c|c|}
\hline Constructs and measures & Sources, adapted from: \\
\hline \multicolumn{2}{|l|}{ Equipment } \\
\hline The equipment was modern looking & Wakefield and Blodgett (1999) \\
\hline $\begin{array}{l}\text { The electronic equipment was } \\
\text { excellent }\end{array}$ & Wakefield and Blodgett (1999) \\
\hline
\end{tabular}

The equipment was of high quality Wakefield and Blodgett (1999)

\section{Design}

I found the interior design visually Reimer and Kuehn (2005) appealing

The interior design was attractive -

The color schemes were appropriate Baker et al. (2002)

The architecture was attractive Reimer and Kuehn (2005)

\section{Space}

The flooring was appropriate

I found my way around easily

Wakefield and Blodgett (1996)

\section{Ambience}

The background music was pleasant Reimer and Kuehn (2005)

The lighting was comfortable

The store had a pleasant smell

The background music was

appropriate

Reimer and Kuehn (2005)

Hightower et al. (2002)

Hightower et al. (2002)

\section{Hygiene}

The service station appeared to by -

hygienic

The store was very clean

Reimer and Kuehn (2005)

The employees were neat and tidy in Reimer and Kuehn (2005) appearance

\section{Functional/employee service quality}

The service in store was delivered

promptly

The staff were helpful

The service was efficient

The staff were trustworthy

The staff were polite

Grace and O'Cass (2004)

Grace and O'Cass (2004)

Grace and O'Cass (2004) ${ }^{\mathrm{a}}$

Grace and O'Cass (2004)

Grace and O'Cass (2004)

\section{Overall Service quality}

The store provided good service

The service was of a very high

quality

The service here suited my needs

The service here is reliable

The service station provided quality Grace and O'Cass (2004) service

\section{Behavioral intentions}

Say positive things about this service station to other people

I would recommend this service

station to someone else

I would encourage friends and

family to go to this service station

I would consider this service station Zeithaml et al. (1996) as my first choice in the future

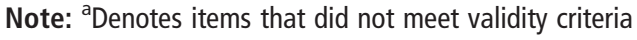

dimensions of service quality perceptions and behavioral intentions. Results support our four-stage model (servicescape $\rightarrow$ employee service quality $\rightarrow$ overall service quality $\rightarrow$ behavioral intentions) which demonstrates that consumers perceive service experiences in an almost "chainlike" manner whereby each service element has a subsequent impact on the next (Figure 2).

Thus, we have shown how tangible cues lie outside the realm of service quality and serve as an antecedent, rather than an element of the construct. Notable authors on service quality (e.g. Parasuraman et al. 1988, 1994; Rust and Oliver, 1994; Brady and Cronin, 2001; Wall and Berry, 2007; Pollack, 2009) have published studies in this area in which tangibles are subsumed under service quality. The difference between these earlier studies and the current study is that the majority of these have not sought to delineate between the servicescape and service quality. Here we can see that for consumers visiting a service or retail store, the service environment is the first aspect of the service that is perceived by the customer and it is at this stage that consumers are likely to form impressions of the level of service they will receive. Indeed, it is very difficult to erase first impressions and it is for this reason, that we believe and have shown that the service environment should be viewed as an antecedent to service quality perceptions. This perspective differs from much of the service quality literature which includes tangibles cues as a core dimension alongside a range of other service quality indicators. Our study demonstrates how it is theoretically more prudent to model the servicescape as a predecessor to service quality evaluations.

Despite other studies in the past having examined the direct effects of the environment on behavioral and loyalty intentions (Harris and Ezeh, 2008), the hypotheses set out in this paper did not specify a direct link between the servicescape and behavioral intentions. Instead it was expected that all servicescape constructs would affect behavioral intentions through service quality perceptions. Not only does the servicescape influence how consumers' perceive the service delivered by service staff, but also directly impacts their impressions of the overall service they received. Furthermore, their evaluations of the servicescape directly affects intentions to return to the service which accentuates the salience of the store environment.

\subsection{Managerial implications and future research directions}

The research presented here offers some guidelines for managers of retail services that can be used as input to improve their service offering. Firstly, it is essential that managers recognize the influence of the servicescape as a marketing tool. Our research has shown that servicescape evaluations directly impact behavioral intentions. Thus, it is imperative to ensure that repatronage intentions are optimized. To meet this end, managers need to consider the importance of both tangible and intangible cues as strategic goals. Our research has found that consumers perceive service quality in terms of intangibles such as the reliability of the service and its efficiency, with tangible cues, otherwise known as the servicescape, having a direct impact on service quality perceptions.

Up until this point, the extant literature has provided little insight into the theoretical differences between service quality and the servicescape. This paper has demonstrated that 
Table II CFA results for full model

\begin{tabular}{|c|c|c|c|c|}
\hline Construct & Factor loading & $t$ value & Composite reliability & $\alpha$ \\
\hline Servicescape & & & 0.79 & 0.79 \\
\hline Equipment & 0.64 & $-{ }^{*}$ & & \\
\hline Ambience & 0.55 & $8.27^{* *}$ & & \\
\hline Space & 0.67 & $9.61 * *$ & & \\
\hline Hygiene & 0.73 & $10.18^{* *}$ & & \\
\hline The staff were polite & 0.82 & $11.27 * *$ & & \\
\hline The staff were helpful & 0.66 & $9.99 * *$ & & \\
\hline The service in store was delivered promptly & 0.67 & $-{ }^{*}$ & & \\
\hline Overall service quality & & & 0.74 & 0.80 \\
\hline The service here suited my needs & 0.66 & $11.69 * *$ & & \\
\hline Behavioral intentions & & & 0.86 & 0.89 \\
\hline Say positive things about this service station to other people & 0.83 & $13.90 * *$ & & \\
\hline I would recommend this service station to someone else & 0.81 & $-{ }^{*}$ & & \\
\hline I would encourage friends and family to go to this service station & 0.80 & $32.82 * *$ & & \\
\hline I would consider this service station as my first choice in the future & 0.64 & $11.41 * *$ & & \\
\hline
\end{tabular}

Table III Results: parameter estimates and hypotheses

\begin{tabular}{|c|c|c|c|}
\hline Structural paths & Overall & Standardized path coefficients & $t$ value \\
\hline H1: Servicescape $\rightarrow$ employee service quality & Supported & 0.66 & $7.58^{*}$ \\
\hline H2: Servicescape $\rightarrow$ overall service quality & Supported & 0.27 & $3.07^{*}$ \\
\hline H4: Servicescape $\rightarrow$ behavioral intentions & Supported & 0.44 & $5.28 *$ \\
\hline H5: Overall service quality $\rightarrow$ behavioral intentions & Supported & 0.25 & $3.39 *$ \\
\hline
\end{tabular}

Notes: *Significant at the $p<0.05$ level

Figure 2 Results: standardized parameter estimates of the model

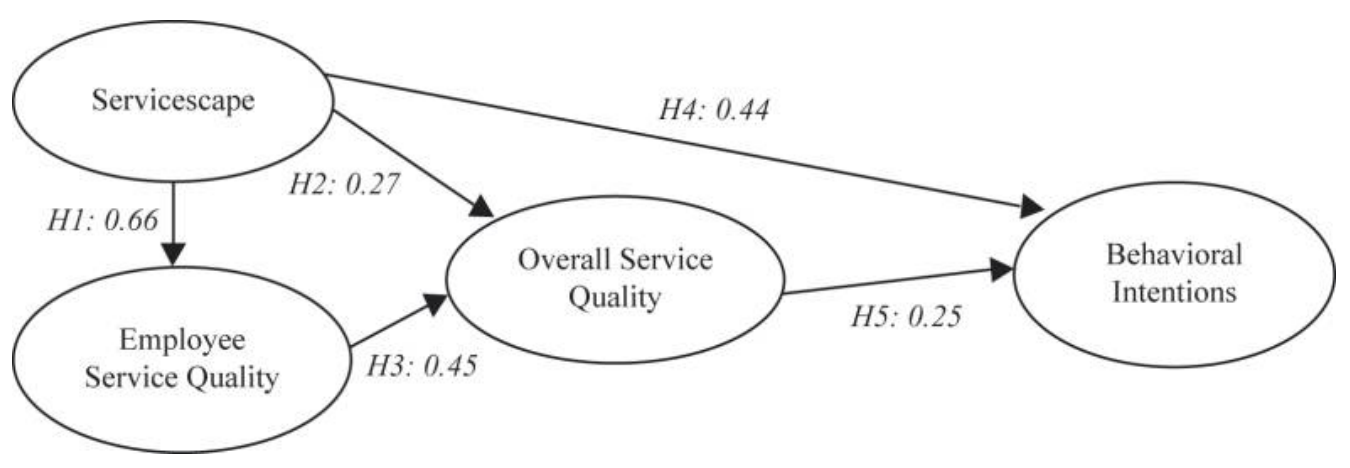

consumers cognitively discriminate between these two constructs, with perceptions of the servicescape directly preceding service quality perceptions. Thus, managers need to be aware of the effect that service environments have in shaping overall service quality evaluations. This is particularly the case as the first point of contact for consumers are tangible cues. Therefore, it is essential that the service environment is managed so that, at a minimum, it matches consumers' expectations of what to expect from such a service and that the service environment is congruent with the service type. Managers must buy into the idea that service environments need to be maintained so as to optimize consumers' 
evaluations of the service quality that they receive. To meet this end, managers must communicate to staff the benefits of maintaining a clean, and well-kept service environment that facilitates customers in achieving their service goals. As with many services, it is very difficult for managers to both retain and attract and "right" kind of staff and of all aspects of the service offering it is the most complex part to manage and control and is likely to be highly variable from one service provider to the next. Therefore, it is very reassuring to see that the physical aspects of the service, which are not variable, hold such value for customers. Because of this, the servicescape should be under constant evaluation and observation by management. While a major overhaul of the design might be both costly and difficult to do, adjustments such as repainting the service environment or adding decorative features may rejuvenate the environment and allow it to maintain its attractiveness to customers. If the upkeep of the servicescape is not prioritized, the likelihood is that customers will begin to patronize competitors.

The cleanliness and hygiene of the service station is a key element of this. In terms of control, this facet of service design is relatively easy to manage. All flooring, outdoor and indoor space should at all times be free from litter and management must oversee regular cleaning of the environment. It is also essential that managers understand that perceptions of the cleanliness of the environment will impact how consumers perceive the service staff. The reasoning behind this is that it seems that customers attribute the upkeep of the store as the responsibility of the staff and therefore it should be realized by management that if they wish customers to perceive staff in a positive light then care should be taken to maintain a hygienic and clean store environment. Equipment and machinery are also key, with managers ensuring that all self-service equipment is in working order and without any mechanical defects. On the whole, constant attention needs to be paid to the servicescape and innovations and ways to improve it should constantly be considered by management.

The current study examined a service station with a retail store attached, however in terms of application, we believe these findings will hold true in any manner of services. The servicescape will impact over all evaluations of services in a wide range of services including; retail, restaurants, financial services and even services offered by government agencies are likely to be judged in this way. Further research should seek to replicate this study to clarify whether this is the case.

\section{Conclusion}

This paper began with the premise that there is theoretical confusion between our understanding of service environments and service quality with no clear distinction made in the literature between the two. Our research suggests that consumers evaluate the servicescape which then leads to linkages to service quality and subsequently to behavioral intentions. Through the provision of a framework that elucidates the evaluative process that consumers engage in, we are given the opportunity to deepen our understanding of how consumers experience services. The SERVQUAL instrument has become a stalwart of services marketing theory, and it is this model that includes tangible cues in its framework. Within this paper we argue that service quality is best described in terms of intangible cues primarily related to the actual service that is delivered by service personnel.
Theoretically it is more sensible that service environments and all their associated tangible cues are seen as distinct from employee related issues the two are quite conceptually different one another. We recognize that customers evaluate services holistically, however the servicescape should be regarded as a primer which molds customers' expectations of the service they are about to receive. Indeed, it is quite possible for an individual to evaluate a service or store based on aesthetics or visual cues only and for this reason it is understandable that servicescape evaluations should serve as an antecedent to service quality perceptions.

\section{References}

Anderson, J.C. and Gerbing, D.W. (1988), "Structural equation modeling in practice: a review and recommended two-step approach", Psychological Bulletin, Vol. 103 No. 3, pp. 411-423.

Areni, C. and Kim, D. (1993), "The influence of background music on shopping behavior: classical versus top-forty music in a wine store", Advances in Consumer Research, Vol. 20 No. 1, pp. 336-340.

Areni, C. and Kim, D. (1994), "The influence of in-store lighting on consumers' examination of merchandise in a wine store", International Fournal of Research in Marketing, Vol. 11 No. 2, pp. 117-125.

Bagozzi, R.P. and Yi, Y. (1991), "Multitrait-multimethod matrices in consumer research", fournal of Consumer Research, Vol. 17 No. 4, pp. 426-439.

Bagozzi, R.P., Yi, Y. and Phillips, L.W. (1991), "Assessing construct validity in organizational research", Adminstrative Science Ouarterlv, Vol. 36 No. 3, pp. 421-458.

Baker, J. (1987), "The role of the environment in marketing services: the consumer perspective", in Czepeil, J.A., Congram, C.A. and Shanahan, J. (Eds), The Services Challenge: Integrating for Competitive Advantage, American Marketing Association, Chicago, IL, pp. 74-84.

Baker, J., Grewal, D. and Parasuraman, A. (1994), "The influence of store environment on quality inferences and store image", Fournal of the Academv of Marketing Science, Vol. 22 No. 4, pp. 328-329.

Baker, J., Parasuraman, A., Grewal, D. and Voss, G.B. (2002), "The influence of multiple store environment cues on perceived merchandise value and patronage intentions", Fournal of Marketing, Vol. 66 No. 2, pp. 120-141.

Bitner, M.J. (1992), "Servicescapes: the impact of physical surroundings on customers and employees", Fournal of Marketing, Vol. 56 No. 2, pp. 57-71.

Bitner, M.J. and Hubbert, A.R. (1994), "Encounter satisfaction versus overall satisfaction versus quality", in Rust, R.T. and Oliver, R.L. (Eds), Service Quality: New Directions in Theory and Practice, Sage Publications, Thousand Oaks, CA, pp. 72-94.

Bone, P.F. and Ellen, P.S. (1999), "Scents in the marketplace: explaining a fraction of olfaction", fournal of Retailing, Vol. 75 No. 2, pp. 243-262.

Brady, M.K. and Cronin, J.J. (2001), "Some new thoughts on conceptualizing perceived service quality: a hierarchical approach", fournal of Marketing, Vol. 65 No. 3, pp. 34-49.

Brüggen, E.C., Foubert, B. and Gremler, D. (2009), "The longitudinal effects of a servicescape makeover", paper presented at QUIS 11: The Service Conference, Wolfsburg, 11-14 June. 
Chebat, J.-C., Chebat, C.G. and Vaillant, D. (2001), "Environmental background music and in-store selling", Zournal of Business Research, Vol. 54 No. 2, pp. 115-123.

Davies, B.J., Kooijman, D. and Ward, P. (2003), "The sweet smell of success: olfaction in retailing", fournal of Marketing Management, Vol. 19 Nos 5/6, pp. 611-627.

Donovan, R.J. and Rossiter, J.R. (1982), "Store atmosphere: an environmental psychology approach", fournal of Retailing, Vol. 58 No. 1, pp. 34-57.

Dubé, L., Chebat, C.G. and Morin, S. (1995), "The effects of background music on consumers' desire to affiliate in buyer-seller interactions", Psychologv and Marketing, Vol. 12 No. 4, pp. 305-319.

Eroglu, S. and Harrell, G.D. (1986), "Retail crowding: theoretical and strategic implications", fournal of Retailing, Vol. 62 No. 4, p. 346.

Grace, D. and O'Cass, A. (2004), "Examining service experiences and post-consumption evaluations", fournal of Services Marketing, Vol. 18 No. 6, pp. 450-461.

Grayson, R.A.S. and McNeill, L.S. (2009), "Using atmospheric elements in service retailing: understanding the bar environment", fournal of Services Marketing, Vol. 23 No. 7, pp. 517-527.

Grönroos, C. (1984), “A service quality model and its marketing implications", European fournal of Marketing, Vol. 18 No. 4, pp. 36-44.

Harrell, G.D., Hutt, M.D. and Anderson, J.C. (1980), "Path analysis of buyer behaviour under conditions of crowding", Fournal of Marketing Research, Vol. 17 No. 1, pp. 45-51.

Harris, L.C. and Ezeh, C. (2008), "Servicescape and loyalty intentions: an empirical investigation", European fournal of Marketing, Vol. 42 Nos 3/4, pp. 390-422.

Harris, L.C. and Goode, M.M.H. (2010), "Online servicescapes, trust, and purchase intentions", fournal of Services Marketing, Vol. 24 No. 3, pp. 230-243.

Herrington, J.D. and Capella, L.M. (1994), "Practical application of music in service settings", fournal of Services Marketing, Vol. 8 No. 3, pp. 50-65.

Herrington, J.D. and Capella, L.M. (1996), "Effects of music in service environments: a field study", fournal of Services Marketing, Vol. 10 No. 2, pp. 26-41.

Hightower, R., Brady, M.K. and Baker, T.L. (2002), "Investigating the role of the physical environment in hedonic service consumption: an exploratory study of sporting events", fournal of Business Research, Vol. 55 No. 9, pp. 697-707.

Hoffman, D.K., Kelley, S.W. and Chung, B.C. (2003), "A CIT investigation of servicescape failures and associated recovery strategies", Zournal of Services Marketing, Vol. 17 No. 4, pp. 322-340.

Hooper, D., Coughlan, J. and Mullen, M.R. (2008), "Structural equation modelling: guidelines for determining model fit", Electronic fournal of Business Research Methods, Vol. 6 No. 1, pp. 53-60.

Hui, M.K. and Bateson, J.E.G. (1991), "Perceived control and the effects of crowding and consumer choice on the service experience", Zournal of Consumer Research, Vol. 18 No. 2, pp. 174-184.

Jacob, C. (2006), "Styles of background music and consumption in a bar: an empirical evaluation", International fournal of Hospitality Management, Vol. 25 No. 4, pp. $716-720$
Johnson, L., Mayer, K.J. and Champaner, E. (2004), “Casino atmospherics from a customer's perspective: a reexamination", UNLV Gaming Research and Review fournal, Vol. 8 No. 2, pp. 1-10.

Keaveney, S.M. (1995), "Customer switching behavior in service industries: an exploratory study", Fournal of Marketing, Vol. 59 No. 2, pp. 71-82.

Kotler, P. (1974), "Atmospherics as a marketing tool", Fournal of Retailing, Vol. 49 No. 4, pp. 48-64.

Kotzan, J.A. and Evanson, R.V. (1969), "Responsiveness to drug store sales to shelf space allocations", fournal of Marketing Research, Vol. 6 No. 4, pp. 465-469.

Lin, I.Y. (2010), "The interactive effect of Gestalt situations and arousal seeking tendency on customers' emotional responses: matching color and music to specific servicescapes", Zournal of Services Marketing, Vol. 24 No. 4, pp. 294-304.

Mehrabian, A. and Russell, J.A. (1974), An Approach to Environmental Psychology, MIT Press, Cambridge, MA.

Menzel-Baker, S., Holland, J. and Kaufman-Scarborough, C. (2007), "How consumers with disabilities perceive 'welcome' in retail servicescapes: a critical incident study", fournal of Services Marketing, Vol. 21 No. 3, pp. $160-173$.

Michon, R., Chebat, J.C. and Turley, L.W. (2005), "Mall atmospherics: the interaction effects of the mall environment on shopping behavior", Zournal of Business Research, Vol. 58 No. 5, pp. 576-583.

Milliman, R.E. (1986), "The influence of background music on the behavior of restaurant patrons", fournal of Consumer Research, Vol. 13 No. 2, pp. 286-289.

Mullen, M.R., Milne, G.R. and Doney, P.M. (1995), "An international marketing application of outlier analysis for structural equations: a methodological note", Zournal of International Marketing, Vol. 3 No. 1, pp. 45-62.

O'Cass, A. and Grace, D. (2008), "Understanding the role of retail store service in light of self-image-store image congruence", Psychologv and Marketing, Vol. 25 No. 6, pp. 521-537.

Parasuraman, A., Berry, L.L. and Zeithaml, V.A. (1985), "A conceptual model of service quality and its implications for future research", fournal of Marketing, Vol. 49 No. 4, pp. 441-450.

Parasuraman, A., Berry, L.L. and Zeithaml, V.A. (1988), "SERVQUAL: a multiple item scale for measuring customer perceptions of service quality", fournal of Retailing, Vol. 64 No. 1, pp. 12-40.

Parasuraman, A., Berry, L.L. and Zeithaml, V.A. (1991), "Refinement and reassessment of the SERVQUAL scale", Fournal of Retailing, Vol. 67 No. 4, pp. 420-450.

Parasuraman, A., Berry, L.L. and Zeithaml, V.A. (1994), "Reassessment of expectations as a comparison standard in measuring service quality: implications for further research", fournal of Marketing, Vol. 58 No. 1, pp. 111-124.

Podsakoff, P., MacKenzie, S., Lee, J.-Y. and Podskoff, N. (2003), "Common methods biases in behavioral research: a critical review of the literature and recommended remedies", fournal of Applied Psychologv, Vol. 88 No. 5, pp. 879-903.

Pollack, B.L. (2009), "Linking the hierarchical service quality model to customer satisfaction and loyalty", fournal of Services Marketing, Vol. 23 No. 1, pp. 42-50. 
Reimer, A. and Kuehn, R. (2005), "The impact of servicescape on quality perception", European fournal of Marketing, Vol. 39 Nos 7/8, pp. 785-808.

Rust, R.T. and Oliver, R.L. (1994), "Service quality: insights and managerial implications from the frontier", in Rust, R.T. and Oliver, R.L. (Eds), Service Quality: New Directions in Theory and Practice, Sage Publications, Thousand Oaks, CA, pp. 1-19.

Ryu, K. and Jang, S.C. (2007), "The effect of environmental perceptions on behavioural intentions through emotions: the case of upscale restaurants", Fournal of Hospitality and Tourism Research, Vol. 31 No. 1, pp. 56-72.

Sherman, E., Mathur, A. and Smith, R.B. (1997), "Store environment and consumer purchase behavior: mediating role of consumer emotions", Psychology and Marketing, Vol. 14 No. 4, pp. 361-378.

Smith, C. and Curnow, R. (1966), "Arousal hypothesis and the effects of music on purchasing behavior", fournal of Applied Psychologv, Vol. 50 No. 3, pp. 255-256.

Sulek, J.M. and Lind, M.R. (1995), "The impact of a customer service intervention and facility design on firm performance", Management Science, Vol. 41 No. 11, pp. 1763-1774.

Summers, T.A. and Herbert, P.R. (2001), "Shedding some light on store atmospherics: influence of illumination on consumer behavior", fournal of Business Research, Vol. 54 No. 2, pp. 145-150.

Turley, L.W. and Milliman, R.E. (2000), "Atmospheric effects on shopping behavior: a review of the experimental evidence", fournal of Business Research, Vol. 49 No. 2, pp. 193-211.

Tuzovic, S. (2009), "Key determinants of real estate service quality among renters and buyers", fournal of Services Marketing, Vol. 23 No. 7, pp. 496-507.

Vilnai-Yavetz, I. and Rafaeli, A. (2007), "Aesthetics and professionalism of virtual servicescapes", fournal of Service Research, Vol. 8 No. 3, pp. 245-259.

Wakefield, K.L. and Blodgett, J.G. (1999), "Customer response to intangible and tangible service factors", Psychology and Marketing, Vol. 16 No. 1, pp. 51-68.

Wakefield, K.L. and Blodgett, J.G. (1996), "The effect of servicescapes on customers' behavioural intentions in leisure service settings", fournal of Services Marketing, Vol. 10 No. 6, pp. 45-61.

Wall, E.A. and Berry, L.L. (2007), "The combined effects of the physical environment and employee behaviour on customer perception of restaurant service quality", Cornell Hotel and Restaurant Administration Ouarterly, Vol. 48 No. 1, pp. 59-69.

Ward, P., Davies, B.J. and Kooijman, D. (2003), “Ambient smell and the retail environment: relating olfaction research to consumer behaviour", Fournal of Business and Management, Vol. 9 No. 3, pp. 289-302.

Yalch, R.F. and Spangenberg, E.R. (2000), "The effects of music in a retail setting on real and perceived shopping times", fournal of Business Research, Vol. 49 No. 2, pp. 139-147.

Yalch, R.F. and Spangenberg, E.R. (1990), "Effects of store music on shopping behaviour", fournal of Services Marketing, Vol. 4 No. 1, pp. 31-39.

Zeithaml, V.A., Berry, L.L. and Parasuraman, A. (1996), "The behavioral consequences of service quality", fournal of Marketing, Vol. 60 No. 2, pp. 31-46.

\section{Corresponding author}

Daire Hooper can be contacted at: daire.hooper@dit.ie

\section{Executive summary and implications for managers and executives}

This summary has been provided to allow managers and executives a rapid appreciation of the content of this article. Those with a particular interest in the topic covered may then read the article in toto to take advantage of the more comprehensive description of the research undertaken and its results to get the full benefits of the material present.

You never get a second chance to make a good first impression. Now there's a saying which should be committed to memory by those responsible for providing pleasant and comfortable environments in which customers can do business - the places we have come to refer to as the servicescape.

When visiting a service or retail store, the service environment is the first aspect of the service that the customer experiences and it is at this stage that they are likely to form impressions of the level of service they will receive. So, is the service environment - the first aspect of the service that is perceived by the customer - merely a dimension within service quality conceptualization or is it a unique construct in itself which precedes service quality evaluations and behavioral intentions?

According to Daire Hooper et al. in "The servicescape as an antecedent to service quality and behavioral intentions" it is the latter. According to their research consumers evaluate the servicescape which then leads to linkages to service quality and subsequently to behavioral intentions. Therefore the servicescape should be regarded as a primer which molds customers' expectations of the service they are about to receive. Indeed, it is quite possible for an individual to evaluate a service or store based on aesthetics or visual cues only and for this reason it is understandable that servicescape evaluations should serve as an antecedent to service quality perceptions.

It is essential, therefore, that the service environment is managed so that, at a minimum, it matches consumers' notions of what to expect from such a service and that the service environment is congruent with the service type. Managers must buy into the idea that service environments need to be maintained so as to optimize consumers' evaluations of the service quality that they receive. To meet this end, managers must communicate to staff the benefits of maintaining a clean and well-kept environment that facilitates them in achieving their service goals.

The purpose of the study, conducted among customers of a retail store, was to develop a theoretical model of servicescapes and to demonstrate how store environment perceptions precede a two-dimensional view of service quality which are then modeled together as antecedents of behavioral outcomes. It found that consumers perceive service quality in terms of intangibles such as the reliability of the service and its efficiency, with tangible cues, otherwise known as the servicescape, having a direct impact on service quality perceptions. A structural model investigated whether the servicescape is an antecedent to the two dimensions of service quality perceptions and behavioral intentions. Results support 
a four-stage model (servicescape $\rightarrow$ employee service quality $\rightarrow$ overall service quality $\rightarrow$ behavioral intentions) which demonstrates that consumers perceive service experiences in an almost "chain-like" manner whereby each service element has a subsequent impact on the next.

As with many services, it is very difficult for managers to both retain and attract and "right" kind of staff and of all aspects of the service offering it is the most complex part to manage and control and is likely to be highly variable from one service provider to the next. Therefore, it is very reassuring to see that the physical aspects of the service, which are not variable, hold such value for customers. Because of this, the servicescape should be under constant evaluation and observation by management. While a major overhaul of the design might be both costly and difficult, adjustments such as repainting or adding decorative features may rejuvenate it enough to maintain its attractiveness to customers. If the upkeep of the servicescape is not prioritized, the likelihood is that customers will begin to patronize competitors.

The cleanliness and hygiene of the area where the service takes place is a key element of this. In terms of control, this facet of service design is relatively easy to manage. All flooring, outdoor and indoor space should at all times be free from litter and management must oversee regular cleaning. It is also essential that managers understand that perceptions of the cleanliness of the environment will impact how consumers perceive the service staff. Equipment and machinery are also key, with managers ensuring that all self-service equipment is in working order. On the whole, management should pay constant attention to the servicescape and innovations and ways to improve.

The study examined a service station with a retail store attached. However in terms of application, the findings are likely to hold true in any manner of services. The servicescape will impact over all evaluations of services in a wide range of services including; retail, restaurants, financial services and even services offered by government agencies are likely to be judged in this way.

( $A$ précis of the article "The servicescape as an antecedent to service quality and behavioral intentions". Supplied by Marketing Consultants for Emerald.) 
his article has been cited by:

. Bekir Bora Dedeoğlu, Halil Demirer. 2015. Differences in service quality perceptions of stakeholders in the hotel industry. International Journal of Contemporary Hospitality Management 27:1, 130-146. [Abstract] [Full Text] [PDF]

. Giacomo Del Chiappa, Luisa Andreu, Martina G. Gallarza. 2014. Emotions and visitors' satisfaction at a museum. International Journal of Culture, Tourism and Hospitality Research 8:4, 420-431. [Abstract] [Full Text] [PDF] 